
Knowledges and Urban Political Ecologies

\title{
Small Town, Great Expectations: Urbanization and Beautification in Leh
}

Judith Müller and Juliane Dame

\section{CpenEdition}

\section{Journals}

Electronic version

URL: http://journals.openedition.org/samaj/4208

DOI: $10.4000 /$ samaj.4208

ISSN: $1960-6060$

Publisher

Association pour la recherche sur l'Asie du Sud (ARAS)

Electronic reference

Judith Müller and Juliane Dame, « Small Town, Great Expectations: Urbanization and Beautification in Leh », South Asia Multidisciplinary Academic Journal [Online], 14 | 2016, Online since, connection on 01 May 2019. URL : http://journals.openedition.org/samaj/4208 ; DOI : 10.4000/samaj.4208

This text was automatically generated on 1 May 2019.

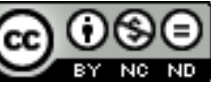

This work is licensed under a Creative Commons Attribution-NonCommercial-NoDerivatives 4.0 International License. 


\title{
Small Town, Great Expectations: Urbanization and Beautification in Leh
}

\author{
Judith Müller and Juliane Dame
}

We gratefully acknowledge the support of the Heidelberg Center for the Environment at Heidelberg University, Germany, for funding this research through the project "Environment and Health in Arid Regions."

We would like to thank the anonymous reviewers for their valuable and constructive comments, which helped us considerably improve this paper. We are thankful to Natasha Cornea and Anna Zimmer for giving us important comments on an earlier version of the manuscript. Julia Poerting, Aditya Ghosh and Ravi Baghel (Heidelberg University) helped edit the final manuscript.

1 Urban modifications have considerably altered the appearance of Leh, a district capital in the Indian Transhimalaya, over the last few years. The beautification project in Leh is concentrated at and around the main bazaar and currently is the most visible and powerful instrument shaping the urban space. It is a subproject under the national "Urban Infrastructure Development Scheme for Small \& Medium Towns" (UIDSSMT, Ministry of Urban Development 2009) and started in December 2013. Construction works block central streets, conveying an insistent sense of efforts to change the town's design to the passer-by. Perceptions on the characteristics of a "beautiful" town differ, as do opinions on the recent metamorphosis of the town, especially of the most important commercial street with historical importance: Leh's main bazaar.

2 Leh, like other Indian cities, is subject to high urbanization rates that create new challenges for infrastructures, urban design, and housing, as well as the urban ecology (Nagendra et al. 2013; Swerts, Pumain and Denis 2014; Vira and Vira 2005). Leh district, homonymous with its capital, is located in the Ladakh region, which is part of the state of Jammu and Kashmir (J\&K). Geographically, Ladakh is separated from the Indian subcontinent by the Great Himalayan Range and shut in by the Karakoram Range towards 
the north. Following Shaw's definition (2013:37), the mountain town represents a small town in the Indian context with less than 100,000 inhabitants. Most of the research on urban studies situated in the Global South focuses on megacities (e.g. Kraas 2007; Kraas et al. 2014) or on peri-urban fringes (Simon 2008) and neglects smaller or medium sized towns, whereas those are the cities with exponential growth that need more consideration in research (e.g. Fahmi et al. 2014; Montgomery 2008; Cohen 2006). The population growth rates of Indian megacities decreased between 2001 and 2011, whereas the rates of smaller towns have steadily grown (Gooptu 2016:217-19). This absence of research is especially acute when it comes to agglomerations in the mountain regions (Mathieu 2003).

We build on previous discussions about urban spaces in India in which "city beautification" projects form an emerging field of research. Those studies deal with different urban terrains, such as the Yamuna riverfront in Delhi (Follmann 2014; 2015) or the development of Delhi as a "world-class city" (Ghertner 2011; 2015), but also in a broader sense with improvement of air quality in Delhi (Véron 2006) or the beautification of Chennai to gain global recognition and capital inflow (Coelho and Raman 2013). In this context, different authors emphasize the increasing influence of emerging Indian middle classes on the creation of urban spaces (Baviskar 2003; Fernandes 2004; Follmann 2014:123; Gandy 2008; Harriss 2007; Rademacher and Sivaramakrishnan 2013:23-24; Zimmer 2015:597).

4 Yet smaller or medium sized cities in India are significantly underrepresented in the studies of Urban Political Ecology (Zimmer 2015:599) and urban beautification in particular (for an exception see Zimmer, Cornea and Véron 2016). In discussing the example of Leh's beautification, we wish to fill this gap and show how beautification has become part of the urban development of a rapidly growing Himalayan town. In this context, we highlight similarities and differences between the processes of beautification in Leh and in larger agglomerations in India. The politics of beautification lead to questions about who gains and who suffers in this process of change and how concepts such as "modern" and "beautiful" are realized in the context of city planning. Unlike in bigger metropolises, the social divide in the case of Leh is less drastic. Nevertheless, imaginaries of financially-strong, local and non-local middle classes largely influence the ongoing transformations.

Our research is based on 20 in-depth interviews conducted between 2014 and 2016 with officials from relevant government departments at the district level, staff of local nongovernmental organizations (NGOs) and employees in the field of tourism, such as tour operators, shopkeepers and restaurant owners. In the context of a broader research project, the interviews focused on urban growth in Leh, its environmental and social implications, urban renewal programmes and beautification. This was supplemented by informal interviews with the residents of different wards of Leh, with divergent socioeconomic characteristics. Findings from household questionnaires conducted for the first author's doctoral research have also been included. In addition, official statistics, policy documents, NGO reports and local press articles as well as secondary sources were analysed.

6 This paper begins with an introduction to the theoretical background and the presentation of socioeconomic change in the study area from a historical perspective. Following that, we present the ongoing UIDSSMT project and introduce the web of actors 
involved in the development and modernization processes. The final part of the paper discusses the contested terrain of urban beautification in Leh.

\section{Urban Political Ecology and urban beautification}

7 Assuming that beautifying a city involves dealing with and reorganizing environmental components essential to urban residents, our analysis builds on Urban Political Ecology (UPE) scholarship, which aims to overcome nature-society dualisms (Swyngedouw and Heynen 2010:80; Zimmer 2010:348). A city's phenotype is deeply entangled with its ecologies, be it water supply, waste management or recreational areas. This becomes even more obvious in the context of Leh's location in the arid Transhimalaya at an altitude of above $3,500 \mathrm{~m}$.

Figure 1

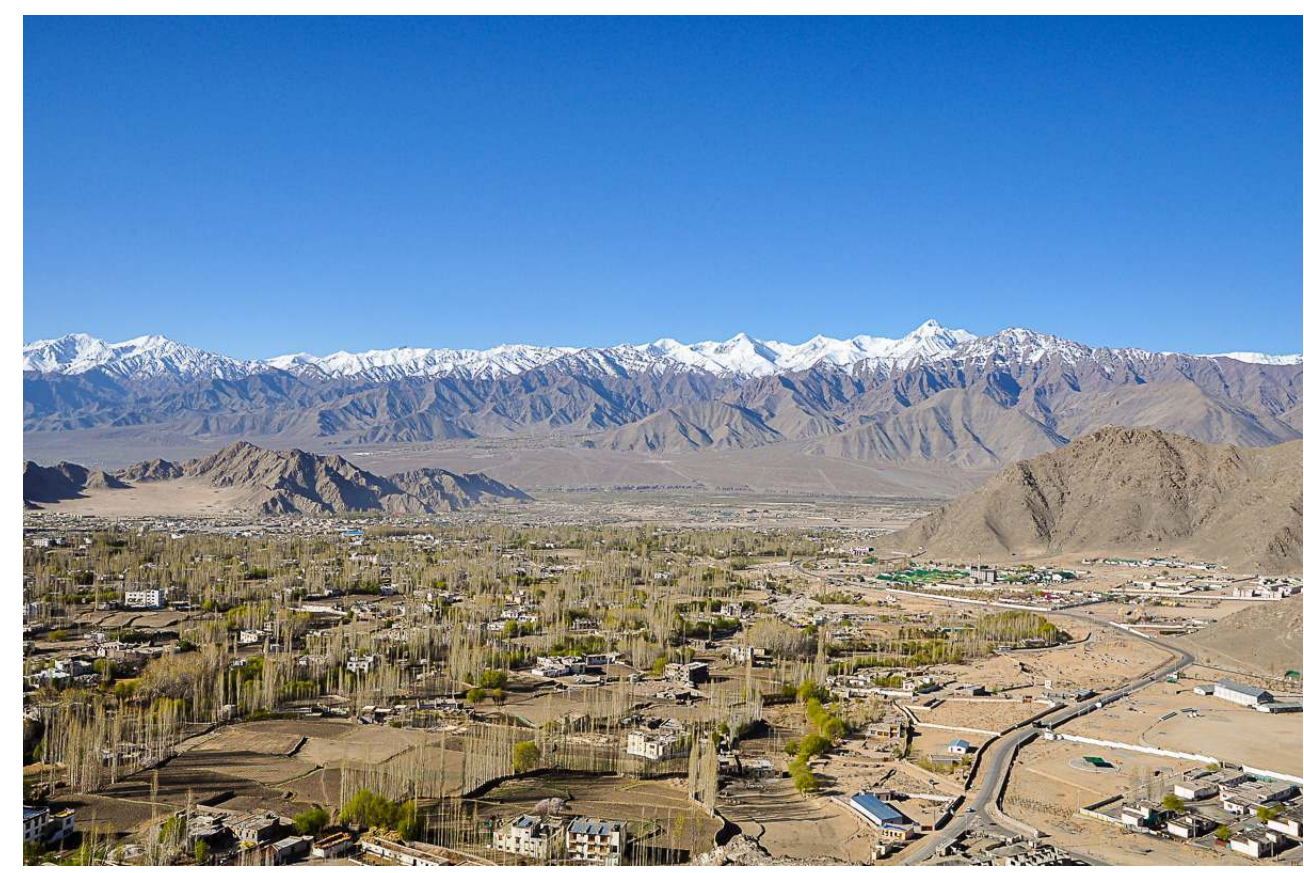

SETTLEMENT AND AgRICULTURAL AREA OF LEH, SITUATED IN THE HIgH ALTITUDE DESERT OF LADAKH, WITH INDUS VALLEY AND STOK RANGE IN THE BACKgROUND

JUDITH MÜLLER, APRIL 2016

Due to the rain shadow effect of the Himalayan Range (Nüsser, Schmidt and Dame 2012:52), the town experiences arid conditions with prevailing seasonality of water availability.

8 UPE understands cities as socio-ecological hybrids, with Swyngedouw (2004:28) describing these as characterized by "... processes that are simultaneously material, discursive, and symbolic." Also Latour (1993:3-11) uses the term hybrid to label mixtures of prevalent dichotomies, such as nature and culture. A major research interest is to detect power structures that form discourses on urban hybrids and to point out which social groups are disadvantaged in certain processes of hybridization (Swyngedouw 2004). In our analysis, we understand urban transformations and particularly beautification measures as processes of hybridizations and materializations of powerful discourses on urban development and modernity. There are certain "ecological imaginaries" 
(Gandy 2006a) that are framed in urban contexts about what nature means and therefore play a crucial role in the process of shaping urban design (Gandy 2006a:66).

The integration of post-structural and postcolonial approaches during the "second wave" (Heynen 2014:4) of UPE (Lawhon, Ernstson and Silver 2014; Ranganathan 2015:1301-02; Zimmer 2015) offers possibilities to embed current power structures in historical and political contexts and thus to reveal continuities and breaks in power distributions. A postcolonial UPE helps to identify prominent discourses on development and modernity in the urban arena. Robinson (2006) elaborates that discourses in urban studies, informed by uncritical understandings of development and modernity, have long been characterized by placing cities into categories such as "Western" or "Third World." In her view, this can be traced back to colonial rule in the early $20^{\text {th }}$ century when the construction of cultural difference was used to reassure the Western self regarding its priority in contrast to the other. She claims that development and modernity are categories that persist in urban theory to this day (Robinson 2006:3-5).

Edensor and Jayne (2012:10) argue that colonial "developmentalist discourses" emphasize alleged deficits, e.g. in terms of infrastructure or governance, of cities in the Global South. This gives momentum to urban elites asserting their modernity through various ways of shaping urban spaces as sites of progress. Indian middle classes, which have grown exponentially since the 1980 s because of economic liberalization, are understood as leaning towards western, capitalist lifestyles (Brosius 2010:10-11; Mawdsley 2004:84-87). This supports the claim that colonial ideas of urban development and modernization still remain present not only in "Western" theory, but also influence India's urban planning (Edensor and Jayne 2012:10; Gandy 2008). Examples are given by Gandy (2008) who traces the discourses on urban modernity in terms of water infrastructures in Mumbai back to colonial rule and shows how these ideas were revived in the post-independence periods and still persist today. Gidwani (2013) shows how middle-class imaginations of modernity form mechanisms of waste management in Delhi that are transformed from informality to private, corporative management.

11 Concepts such as modernity and development moreover materialize as socio-ecological processes that are highly influenced by urban elites: “... urban political ecology more explicitly recognizes that the material conditions that comprise urban environments are controlled, manipulated and serve the interests of the elite ..." (Heynen, Kaika and Swyngedouw 2006:6).

Beautification is based on aesthetic aspects of urban renewal (Carlino and Saiz 2008:1). It has been a worldwide phenomenon and is also a widely used term in present Indian urban planning. Ideas on beautification in India are inspired by conceptions of city planning that began during the $19^{\text {th }}$ century in Europe and the United States (Carlino and Saiz 2008:1; Monclús 2000:57). These ideologies began being implemented during the postindependence modernist urban development period under Nehru (Tiwari et al. 2015:6970).

13 Beautification in Indian cities is characterized by the "practice of 'sanitized' and 'deodorized' urban planning” (Tiwari et al. 2015:69) and is influenced by imaginations of middle classes (Fernandes 2004; Gooptu 2016:220). For a long time, beautification schemes were limited to large cities like Delhi, e.g. to enhance its role as a world-class city (Ghertner 2011; 2015). Only recently have small (but emblematic) towns like Gangtok in Sikkim or Leh in Ladakh become targets of such strategies. 


\section{Transmontane trade history and Leh's development as the district capital}

14 Contemporary attempts to redefine the appearance of Leh can only be understood against the background of historical and socioeconomic change. Despite its frequent characterization as "Little Tibet" to this day, Ladakh was probably only part of the Tibetan Empire from the $7^{\text {th }}$ or early $8^{\text {th }}$ century until the year $842 \mathrm{AD}$ (Luczantis 2005:66; Petech 1977:9-10). Following this period, Ladakh was an independent kingdom, which expanded into what is now Western Tibet, until it was finally reduced to the size of the latter-day region, and the terrain of Spiti. In the $15^{\text {th }}$ century, Leh was raised to the region's capital and gained political and economic importance. The kingdom of Ladakh prospered due to the trade in Pashmina wool between Tibet and Kashmir (Rizvi 2012:110) which is symbolized by the construction of a new king's palace in the $17^{\text {th }}$ century, overlooking the old town of Leh that still stands today (Rizvi 1996:69).

The kingdom collapsed in 1834, when Ladakh was invaded by the Dogra under Raja Gulab Singh of Jammu, and lost its independence in 1842. The region was incorporated into the Princely State of Jammu and Kashmir and came under indirect rule of the British colonial power in 1846 . During the $19^{\text {th }}$ and early $20^{\text {th }}$ century, Leh became an important crossroads of the Transkarakoram and Transhimalayan trade of luxury goods (e.g. spices, cotton and silk cloths, turquoise and jewellery) on one of the main routes linking the South Asian subcontinent with Central Asia (Rizvi 1999). At the end of the $19^{\text {th }}$ century, Leh had a population of some 2,500 inhabitants, which increased heavily during the summer because of the influx of merchants. Due to Leh's rising importance as a trade town, the wazir [administrative officer] of Ladakh at that time ordered the construction of a bazaar in 1846 (Dollfus 1997:150-51). It hosted 130 shops in 1888 (Gazetteer of Kashmír and Ladák 1890:563) and has been the main commercial centre ever since. Despite the wealth that trade brought to the region, the majority of Ladakhis remained poor. Their livelihood sources were combined mountain agriculture consisting of crop agriculture and animal husbandry, or the involvement in intraregional trade and barter activities (Dollfus 1997:148; Dame 2015). A few privileged families had an advantage as they maintained family ties with almost all the home regions of the traders (Rizvi 1999:75-76; Ghani Sheik 2010; Fewkes 2009:89-93).

The situation changed with the partition of India and Pakistan and the end of British rule in 1947. Ladakh was integrated into the Indian Union as a component of the State of Jammu \& Kashmir, became a borderland of international geopolitical importance and lost its function as a crossroads of trade. The post-colonial development of Leh was affected by a disproportionate demographic development. Between 1981 and 2001, the urban population more than tripled from 8,718 to 28,639 (Census of India 2001; 2011). The last census, conducted in 2011, shows a less dramatic increase of population with 30,870 inhabitants officially living in Leh town (Census of India 2014). ${ }^{1}$ However, this urban population is underestimated to a great extent as the floating population, comprising seasonal and labour migrants, tourists and defence personnel, are not taken into account (Goodall 2004:221).

17 Today, the main factor of urban economic and spatial growth is an ever-increasing tourist influx. Leh district was first opened to international travel in 1974 and quickly became a 
popular tourist destination, especially for those in search of a Buddhist Shangri-La. In the last decade alone, tourist numbers have multiplied by more than five times, mainly due to an increasing number of domestic tourists visiting Ladakh. In 2008, the number of domestic tourists surpassed foreigners for the first time. This group comprised $67 \%$ of the 181,301 tourists who arrived in Leh in 2014. ${ }^{3}$ There are several reasons for this increase. First, a growing Indian middle class can afford to travel and second, it has become much easier to reach Ladakh by air. A third reason is the Bollywood film "Three Idiots," which was released in 2010 and helped the region gain wide public attention thanks to the final scenes shot at the shore of Ladakh's Pangong Lake. The peak tourist season is between May and September, when labour migrants from Kashmir, Bihar and other parts of India and Nepal also arrive in Ladakh ${ }^{4}$ to work on construction sites and in the tourism business. During this time, the population almost triples (Alexander and Catanese 2014:351). Leh is of central importance to the whole district because of its crucial infrastructure such as transportation, health care as well as educational, commercial and administrative facilities.

Leh thus still functions as a central exchange hub for merchants and travellers of different origins: nowadays they are mainly tourists from around the world, traders from Kashmir and other parts of India, as well as local merchants. The main bazaar, as a centre of this exchange, is an L-shaped street located in Leh's old town and is characterized by strong seasonality.

Figure 2

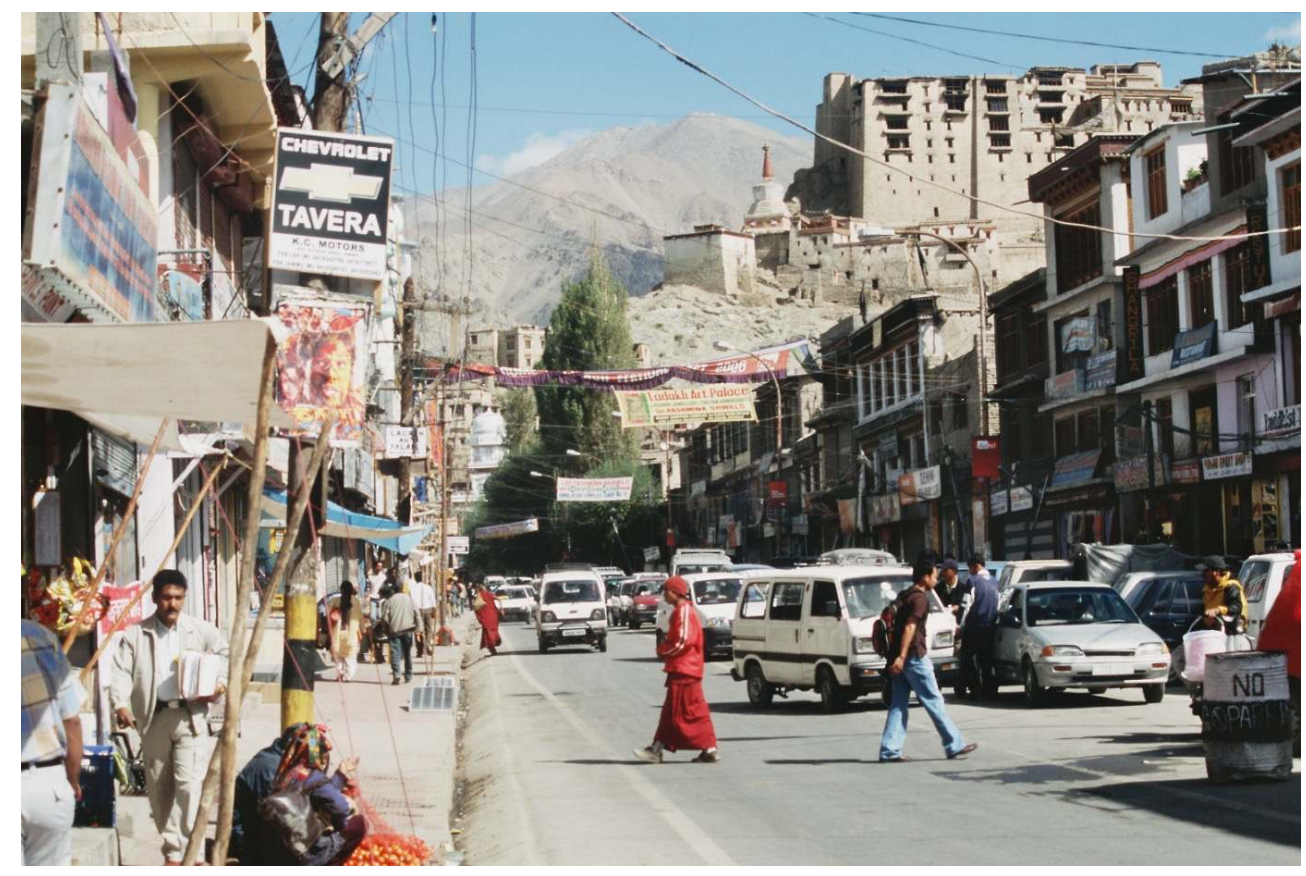

VIEW OF LEH'S VIBRANT MAIN BAZAAR BEFORE BEAUTIFICATION

JULIANE DAME, OCTOBER 2006

During the winter months, the roads connecting the Indian lowlands and Leh are closed, a limited amount of goods reaches the town by plane and only a few tourists visit Ladakh, which leads to reduced commercial activities in the bazaar. During the summer season, one can find anything that suits the needs of travellers and fits into the image of Ladakh as displayed in travel books and magazines: jewellery, shawls, antiques, fabrics, prayer 
flags or trekking equipment. Visitors walk along the historic bazaar and take photos of the old royal palace that overlooks the town. Somewhere between tourists, traders and the local population passing by, women sitting at the edge of the pedestrian walk find their space to sell homegrown vegetables. In the backstreets, Ladakhis buy household goods, bread in the bakery street or go to one of the Muslim butchers. The main bazaar is thus a vibrant and busy street and at the same time represents the most visible space of current urban change in Leh. Its historical entrance gate was destroyed when the bazaar was opened for cars in the 1970s (Rizvi 1996:79) and many new buildings with shops and restaurants have continued to emerge up to this day, parallel to the increasing number of incoming tourists.

19 Commercial, tourist and road developments have not only modified the bazaar area, but also the whole townscape in the last decades. Those who can afford it have left the densely inhabited old town with its infrastructure deficits and moved into the sections of Leh where agriculture is still practiced (Alexander and Catanese 2014:348). Earlier, because of its key importance for the food supply, agricultural land could not be turned into commercial plots. However, since tourism has replaced agriculture as the main source of income, hotels or guesthouses have been built in the once-agricultural fields or they are widely left fallow. The functional centrality of Leh has encouraged many villagers to move to the urban centre, at least for a major part of the year (Goodall 2004). To accommodate the (seasonal) migrants and to manage the rapid urban expansion, new wards have been established since the 1990s, such as Ibex or Housing colony. This rapid urban development creates new challenges for urban planning and is the starting point for debates on the town's restructuring.

\section{Modernizing Leh or conserving cultural traditions?- Contested urban change}

In 2005, a committee consisting of actors from the district-level "Ladakh Autonomous Hill Development Council" (LAHDC/Hill Council), NGOs and local societal and political elite in Ladakh formulated the "Ladakh Vision 2025" document as a basis for future development in the region. With regard to Leh it stresses the need for urban change: "To provide the growing population of Leh town with modern civic amenities, while focusing on restricting the ever-increasing numbers dependent on it (especially by discouraging the rural-urban migration pattern), and also addressing its ecological and environment related concerns" (LAHDC 2005:31).

Pointing out the challenges of urban growth, the document expresses a need for restructuring the town. Yet, for the most part, the proposed actions have not been carried out by the regional government (Rigzin 2016).

The following section sheds light on the UIDSSMT scheme, which is currently the most extensive programme with the aim of reducing the mentioned shortcomings. Subsequently, the different actor groups, which play a role for reshaping the urban centre, are introduced. 


\section{Dynamics of shaping urban design and the JNNURM mission}

The reconstruction of the main bazaar has been at the centre of political debates in recent years. The regional Hill Council government decided to "... revive and facelift the historical Leh town, and to save it from further degradation from the present chaotic state" (Reach Ladakh 2011a). Renewing historic Leh would mean to include "traditional and contemporary characters" in the façade of a building (Reach Ladakh 2011a).

These construction works are taking place under the Jawaharlal Nehru National Urban Renewal Mission (JNNURM), a state-driven programme to modernize and improve infrastructure in Indian cities. The official aim of the JNNURM mission is “... to encourage reforms and fast track planned development of identified cities. Focus is to be on efficiency in urban infrastructure and service delivery mechanisms, community participation, and accountability ..." (Ministry of Urban Development 2011:5). Its subscheme for small and medium sized towns, ${ }^{5}$ UIDSSMT, was launched in $2005^{6}$ (Ministry of Urban Development 2011). Successful applicants for the UIDSSMT receive support in actions such as urban renewal, water supply, sanitation, solid waste management, drainage, sewerage, storm water removal, roads, parking lots, development of heritage areas and the preservation of water bodies (Shaw 2013:45; Sridhar, Reddy and Srinath 2011:68). The regional Leh Hill Council's project proposal under UIDSSMT was approved in spring 2013 and comprises a total calculated cost of approximately 217 crore Indian Rupees, equivalent to roughly 30 Million Euros, a project size that is novel to Ladakh (Ministry of Urban Development 2014). Funds are shared with $90 \%$ contribution from the central government and $10 \%$ contribution from the J\&K Government. State ministries and their corresponding offices such as the Public Works Department in Leh are projectimplementing agencies.

Beautification of the main bazaar is a part of the UIDSSMT scheme that the semiautonomous Hill Council applied for. 
Figure 3

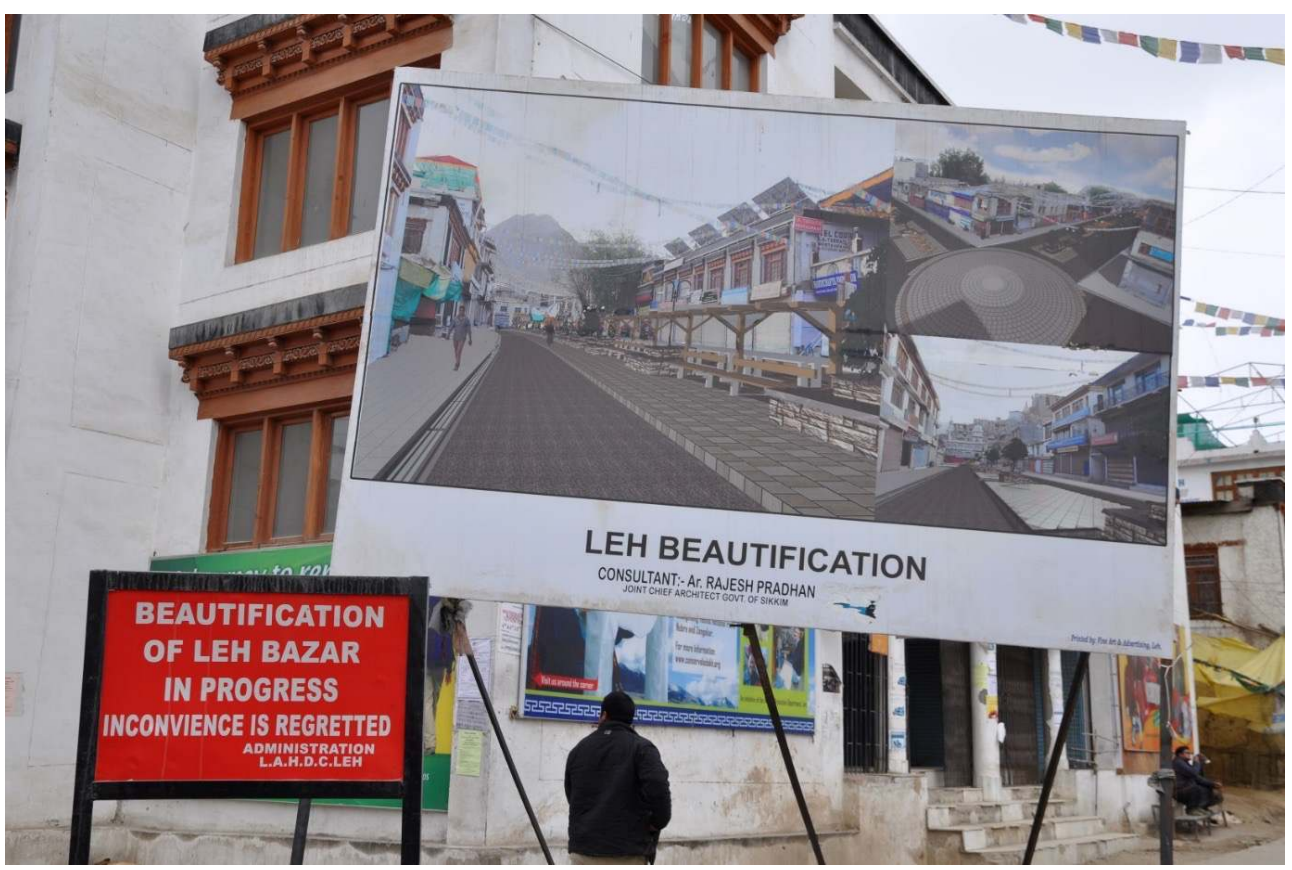

MODEL PLAN FOR THE MAIN BAZAAR AFTER THE EXAMPLE OF GANgTOK, SIKKIM JUDITH MÜLLER, MARCH 2015

The sketched outlay planned to turn the main commercial street into a pedestrian zone. By the beginning of 2016, traffic had been banned, old trees at the main bazaar felled and several old buildings demolished for the construction of new ones.

Figure 4

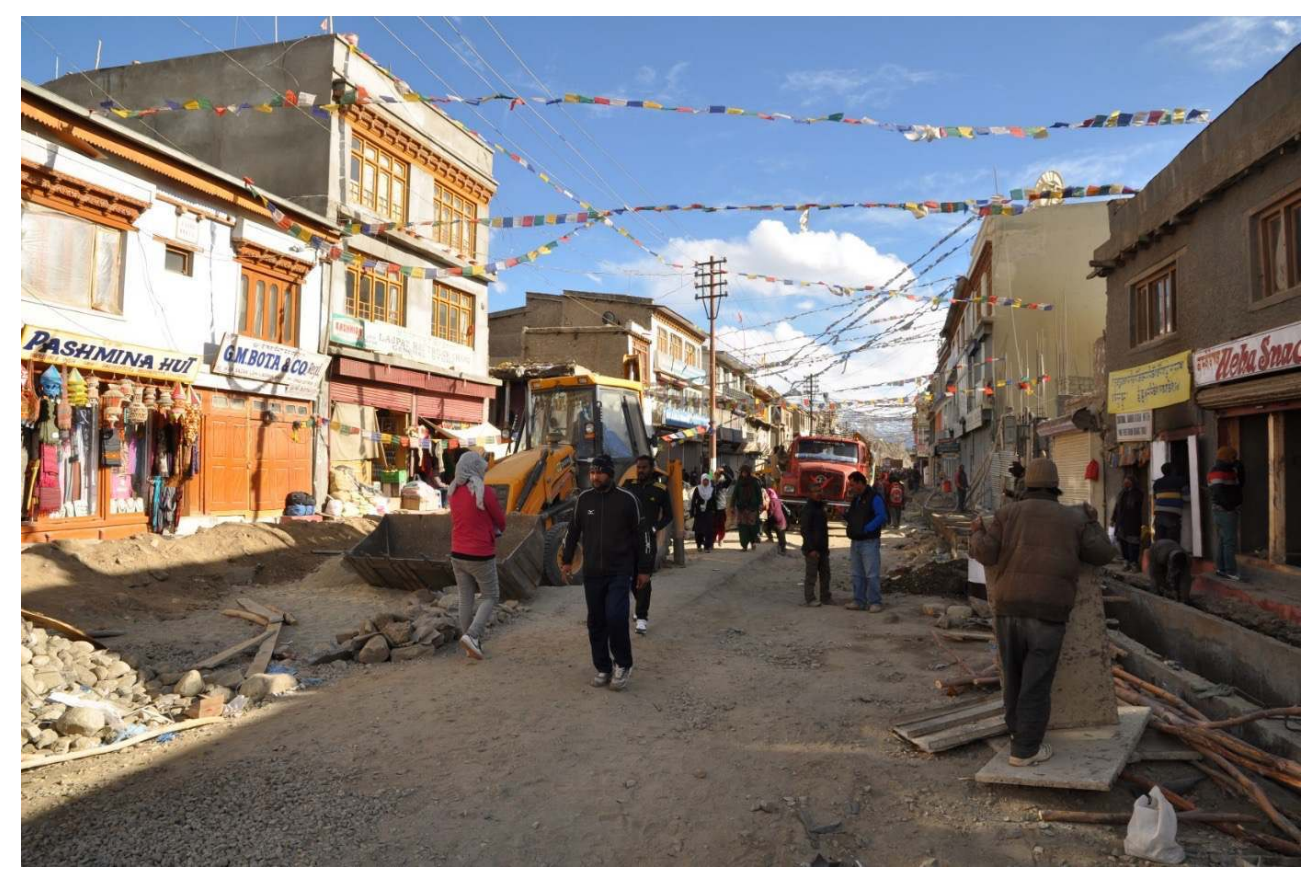

THE TRANSFORMATION OF THE MAIN BAZAAR IN LEH

JUDITH MÜLLER, APRIL 2015 
Benches and flowerpots had been set up and a space in the middle of the street for "people that come to enjoy and sit" had been created.

Figure 5

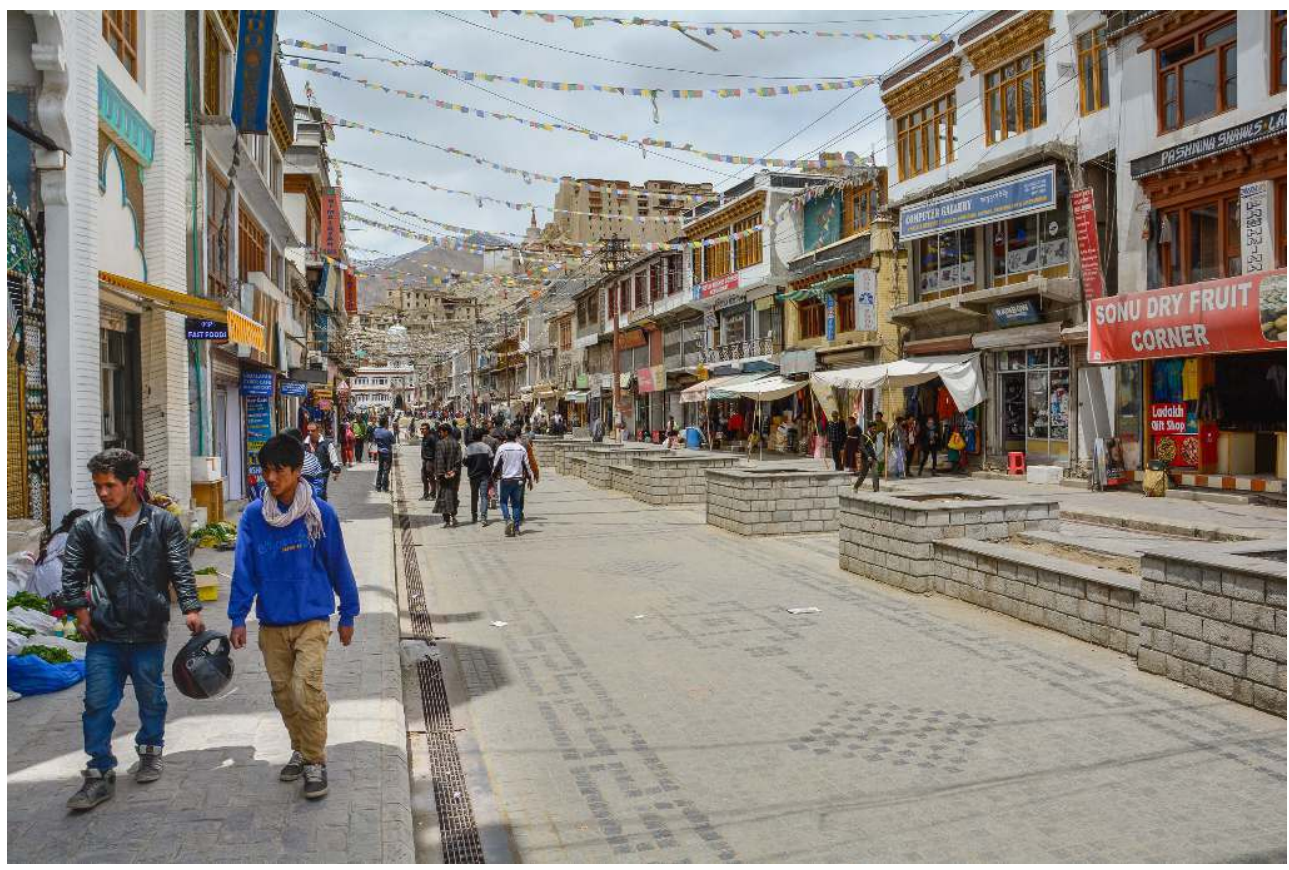

NEW DESIgN OF THE MAIN BAZAAR WITH POTENTIAL FLOWER POTS IN THE MIDDLE OF THE STREET JUDITH MÜLLER, MAY 2016

The new design of the main bazaar was sketched by a town planner from Sikkim. In 2011, the Chief Executive Councillor of the Hill Council invited him to draft a plan following the example of the renewal of MG Street in Gangtok (Reach Ladakh 2011a; Epilogue 2011:4041). Gangtok, which had been selected under the UIDSSMT in 2005, represents a preferential model for urban development due to its perceived cultural "closeness" to Leh as a small, Buddhist-dominated mountain town. ${ }^{8}$

Further efforts to beautify Leh include the development of the old town for tourist potential under another state-led programme called Rajiv Awas Yojana (RAY) [Slum-free cities] (MC and LAHDC 2012), the creation of a park adjacent to the main bazaar, or the construction of new shopping complexes. The RAY scheme ${ }^{9}$ was approved by the Indian government as an extension of JNNURM's "Basic Urban Services to the Poor" scheme (Roy 2014:141) and is supposed to make India "slum free" by 2022. The objectives are to provide housing, basic infrastructures and social services in defined slum areas. The scheme was also accepted for Leh and is implemented by the Municipal Committee ${ }^{10}$ and the Public Works Department. ${ }^{11}$ A project report (MC and LAHDC 2012) which has been prepared in consultation with the local NGOs Ladakh Arts and Media Organization (LAMO) and Leh old Town Initiative (LOTI) documents how Leh's old town is supposed to be upgraded. Under JNNURM's "Integrated Housing and Slum Development Program" (IHSDP), eight "slums" were identified in the old town or in close proximity. The government entities state:

... the old town historic area has gross infrastructure deficiencies and poor housing conditions as a result of which it is in a slum-like condition, despite being historic in nature on the lines of religious towns in other parts of India. (MC and LAHDC 2012:12) 
Another typical element of beautification is to create green spaces in the city (Fernandes 2004; Zimmer, Cornea and Véron 2016)-a process that can also be observed most recently in Leh. The first "Eco-Municipal Park" (Reach Ladakh 2015) was inaugurated at one end of the main bazaar in June 2015 and is designed for the recreation of elderly people on the one hand and as a tourist attraction on the other. The park displays an ensemble of benches around a water fountain and lawns.

Figure 6

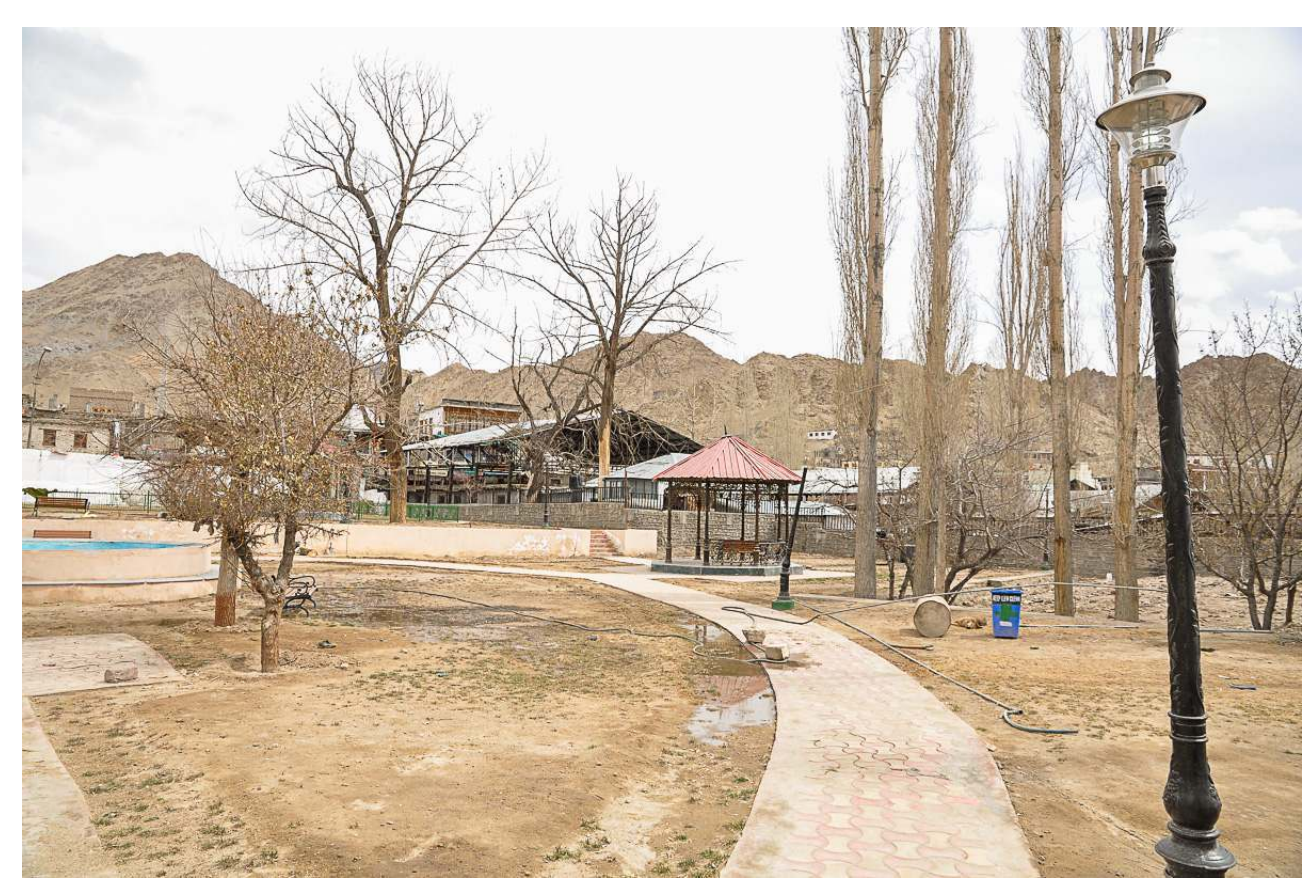

THE NEWLY CONSTRUCTED RECREATIONAL "ECO-MUNICIPAL PARK" ADJACENT TO THE MAIN BAZAAR JUDITH MÜLLER, MARCH 2016

Construction of such a socio-nature is a typical example of the ecological imaginaries of urban spaces by the elites. It illustrates the tension of efforts to improve the living conditions of the inhabitants of Leh on the one hand, and the felt need to adapt urban design to the perceived imaginaries of tourists who increasingly stem from emerging Indian middle classes, on the other. Yet contrary to other cases in India where parks have been created on sites of former slum settlements (e.g. Zimmer, Cornea and Véron 2016), the urban park has been designed on a terrain which had been a recreational space in colonial times and was afterwards used for administrative buildings ${ }^{12}$ and therefore engendered no direct conflicts.

\section{Leh as an arena of negotiations on urban development: introducing the web of actors}

Different actors, including state officials, the Hill Council, several NGOs, religious groups, and parts of the local population put forward diverging ideas and concepts of "development" and "modernization" in general which are linked to beautification in particular. As a basis for further discussion, it is therefore important to shed light on a powerful discourse about Ladakh after Indian independence in 1947, which has been a key argument for development programmes. It is the imagination of Ladakh as a 
peripheral, "backward" and "marginalized" region (van Beek 1996; 1999). While this rhetoric had already been employed in the $19^{\text {th }}$ and early $20^{\text {th }}$ century, the first Indian Prime Minister, Jawaharlal Nehru, took it up during his visit to the region in July 1949 when he stated: "In Ladakh you are backward ... We have great things to do in Ladakh. Poverty must be eradicated, cloth must be provided, new forms of employment created, hospitals and schools must be established and trade must be expanded" (Amrita Bazar Patrika, 9 July 1949, cf. van Beek 1996:155). The integration of the former trade junction into the Indian Union has led to the implementation of development programmes in Ladakh since the 1950s (van Beek 2000:256; Dame and Nüsser 2008:25-6). These interventions were part of a regulated and state-led economic and development policy and implemented within the 5-year plans designed by the Government of India (GoI) in Delhi. ${ }^{13}$ Since the early 1990s, neoliberal reforms have aimed at market-oriented development (e.g. Mooij 2007), which is also reflected in the development plans of Ladakh today. The set of programmes implemented by government departments at the district level follows the ideas of modernization and supports economic development according to the political agendas drafted in Delhi without special reference to regional peculiarities. The large urban development project under UIDSSMT currently being implemented in Leh, is congruent with these visions of modernity.

29 At the same time, Ladakhi politicians hope to create an urban centre that recognizes Leh's historical heritage and aspire to foster economic growth in the tourism sector through the same programme. Yet their limits in power are closely linked to the semiautonomous status of the region. Dating back to the 1960s, political struggles and agitations aimed at enhanced local participation in political processes. ${ }^{14}$ It was hoped a greater extent of autonomy would increase power to shape political discourses and to pursue regional development visions. In 1995, the GoI finally granted the constitution of a "Ladakh Autonomous Hill Development Council" (van Beek and Bertelsen 1997; van Beek 1999). However, the high expectations, which had been associated with the semiautonomous status, could not be met (van Beek 1999; 2000). To this day, politicians from the region argue for further autonomy and a Union Territory (UT) status for Ladakh. They continue to build on the image of a peculiar and marginal high-mountain region as well as on the "step-motherly" treatment by Jammu and Kashmir State (van Beek 1999). Here, power is mainly expressed through financial relations: while the Hill Council is able to draft development plans, the budgets need approval at the state level. Van Beek (2008:183) confirms that “... the council and other agencies ... try to navigate between popular demands, national and state government priorities, and those of other donors, frequently without much opportunity or capacity for local direction of the overall trajectory of development and modernisation."

Besides the Hill Council, a number of non-governmental actors exert control over Leh's future development at the regional level. This group of actors is characterized by personal interlinkages, often across scales, and with varying degrees of power. The first NGOs in Ladakh were established during the 1980s, which is linked to the initiative of foreigners who came to the region after its opening in $1974 .{ }^{15}$ External visions of development continue to shape their work to this day, be it through close connections of Ladakhi NGOs with individuals or funding organizations from outside Ladakh. At the same time, government departments or NGOs operating as project implementing agencies on the ground merely enact political decisions made at the national level. ${ }^{16}$ Yet, NGOs in Ladakh have a strong influence on regional politics, which is not only by virtue of 
their work but is also visible in the career paths of Leh's political elite. Notably key members of the Ladakh Ecological Development Group (LEDeG) have been influential in the struggles for autonomy in the 1990s and were among the first political leaders of the newly established Hill Council in 1995 (van Beek 1999).

Some NGOs are involved in the preservation of the old town and its heritage. Among them, the international NGO Tibet Heritage Fund (THF) and its local counterpart LOTI deal with the conservation of the historic old town of Leh by rehabilitating and preserving its vernacular architecture-an ensemble of some 200 houses considered important heritage of "Tibeto-Himalayan urban architecture" (Alexander and Catanese 2014:348). In 2006, THF and the Hill Council signed a Memorandum of Understanding to cooperate in preserving Leh's old town (Alexander and Catanese 2014). Apart from THF, LAMO has been involved in a social initiative on the development of the old town through various initiatives such as the "Neighbourhood Project-Old Town Leh" since 2010. LAMO restored the old Munshi [king's secretaries] house below the palace of Leh and uses the space for exhibitions and workshops.

The inhabitants of Leh form a heterogeneous group of actors, which do not fit into a single category. Definitions of belonging to a group are bound to different scales, be it the extended household, social institutions such as the "groups of ten houses," the village or hamlet community, or a religious community (Dollfus 1989). The "traditional" social structures of the Buddhist communities, which represent the religious majority in Leh district, differentiates four hereditary castes (rigs): royalty, nobility, commoners and lower castes (Aggrawal 2004; Dollfus 1989). Most of the inhabitants belong to the caste of the commoners. Yet within the social organization, it becomes apparent that families, which belong to the nobility, assume influential positions in the government or private businesses (Aggrawal 2004). ${ }^{17}$ In a context of socio-economic change, which is generally characterized by a shift from subsistence-oriented agriculture as the economic mainstay to diversified livelihood strategies (Dame 2015), monetary income options have led to growing economic disparities in the region. Moreover, economically weaker groups are mainly those who have moved to Leh from rural areas in Ladakh and migrant labourers from other parts of India and from Nepal.

Tourists represent another important group of actors whose expectations have an impact on urban development. Here, a shift has been visible in the recent years. Travellers often have a romantic vision regarding cultural associations and touristic highlights (e.g. Buddhist monasteries) of the former crossroads of trade and its historical heritage, which is also often labelled "Little Tibet." Today, demands of domestic tourists dominate the discourses on urban restructuration, as they are increasingly stimulating to the local economy. Ladakh has found a place in the public awareness and is no longer only perceived as "dangerous" due to its location in a disputed border region. Today, Leh, and especially its main bazaar, serves as a place of leisure, shopping and recreation.

\section{The contested terrain of beautification processes}

The UIDSSMT project in Leh is a visible discursive manifestation and representation of power. Various actors (re)create a multitude of discourses that materialize as a hybrid urban nature. The web of actors encompasses different, interdependent spatial scales and they are characterized by varying degrees of power. Issues of urban change are debated 
both in private and public spaces such as households, tea stalls, on the street, in political meetings and other social spaces.

India as a nation state exercises strong political influence through development schemes, which follow ideas of modernity and economic growth and are, in most cases, characterized by technocratic solutions (Gandy 2008:116). During the inauguration of the UIDSSMT project in December 2013, the District Commissioner (DC) Simrandeep Singh, the highest ranking officer from J\&K state in the district, praised the project as “... incomparable in the history of Leh" (Reach Ladakh 2013). This supports Roy's (2014:141) observation, which calls the JNNURM scheme "a new type of postcolonial government" that focuses on urban infrastructure development to further liberalize the economy and thus create Indian “world-class cities" (Follmann 2014; Ghertner 2011, 2015).

A pursuit of economic growth is also visible in the Hill Council's approach to urban development. Members mention the increasing population and growing numbers of visitors to Leh as reasons for the need of the UIDSSMT scheme. This is also apparent from the council's initial application document for the scheme, which states that Leh is to be further developed as a tourist destination. A government official specifically argues for the beautification of the bazaar:

... tourists also come lots in number. They don't have a place where they can have a relaxed moment. And the third one is because the Leh bazaar ... was an ancient trade centre. So our aim is to make this bazaar traffic free, also with this trade centre. And also we will have some place there to have cultural activities ... ${ }^{18}$

The ongoing processes in Leh are embedded in imaginaries of urban development and modernity and closely interlinked with the larger context of other beautification projects undertaken in India. Ghertner (2015) argues that urban governance is following hegemonic, visual representations of an imagined modernity. His research shows that instead of following administrative urban planning regulations, "rule by aesthetics" would guide urban renewal in Delhi. The construction of such "aesthetic" architecture is legitimized often without a legal basis, whereas slum settlements that are in fact legal but don't fit with a world-class city image are demolished. Urban beautification in Leh highlights the importance of aesthetics: besides official renewal measures, private demolition and construction works in the main bazaar that don't follow any legal guidelines continue and appear to be accepted..$^{19}$ 


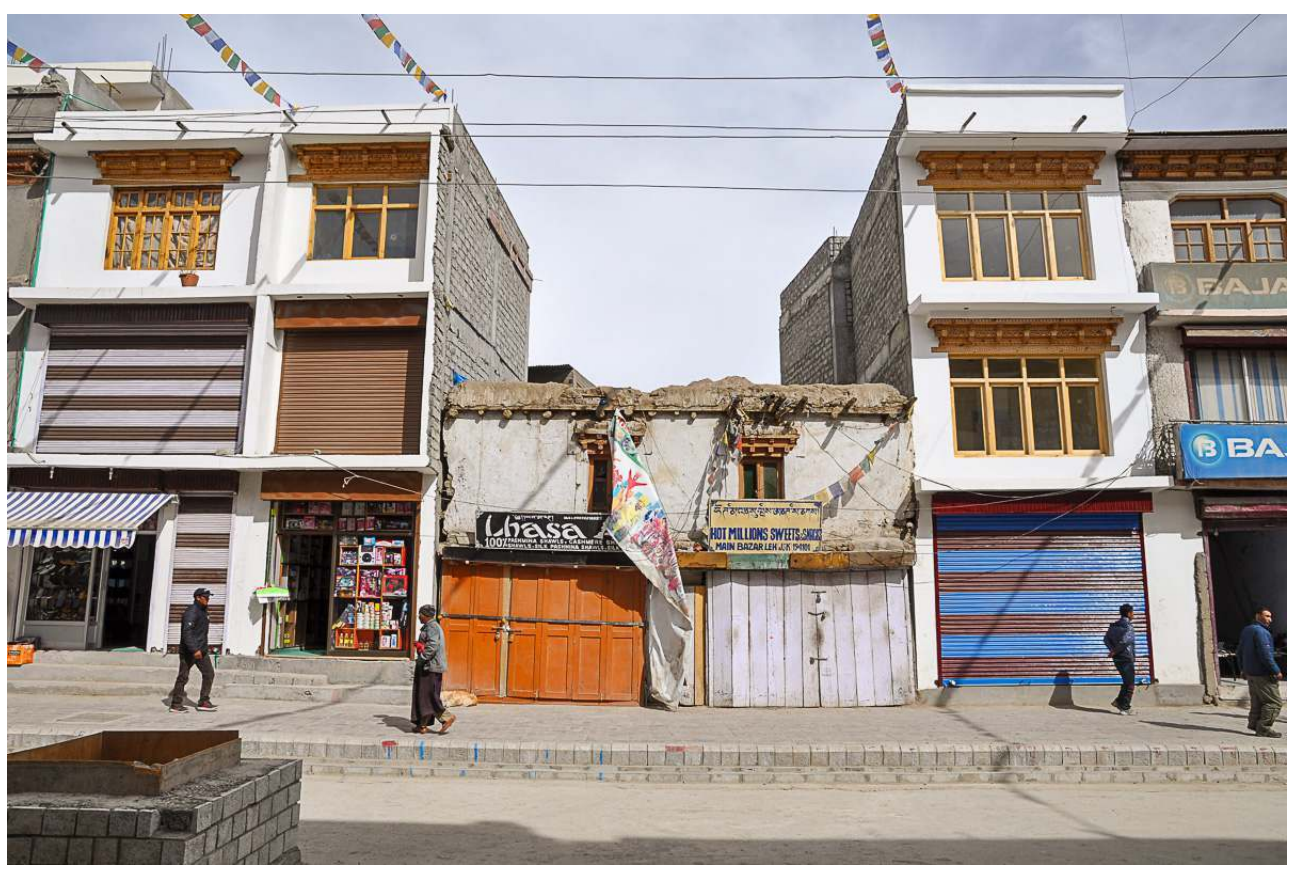

OLD ARCHITECTURAL STRUCTURE BETWEEN TWO RECENTLY CONSTRUCTED BUILDINGS IN THE MAIN BAZAAR

JUDITH MÜLLER, MAY 2016

The RAY scheme is another example of an urban development project (Roy 2014:142).

Here, slums are not destroyed nor are slum-dwellers resettled, like in other cases (Anand and Rademacher 2013; Baviskar 2003; Follmann 2014; Ghertner 2015:11-15). They are instead transformed into "governable entities" (Gandy 2006b:385) with potential for further economic development. In the case of Leh, the so-called slums are different from most informal settlements in Indian metropolises. The Government of India and UN habitat define slums as often informally-built settlements, which are characterized mainly by degraded housing and living conditions, insufficient access to water as well as health risks (Nijman 2010:11). The living conditions in Leh's designated slum areas differ from this description. Infrastructures are widely deficient, but in general, basic housing, water, and health requirements are met (Alexander and Catanese 2014:352). In this context, it is important to highlight that these areas, even though defined as "slum-like" by local entities, are not perceived as "slums" by the citizens of Leh. Under RAY, vernacular architecture in Leh has been demolished and replaced by new buildings, street lights have been installed, and sanitation has been enhanced. These interventions, intending to improve the living conditions of the local inhabitants and enhancing tourist development, are in conflict with the efforts of LOTI, which focus on preserving vernacular architecture in the old town. RAY is in its initial phase; it remains to be seen whether preservation attempts and state-led policies remain in conflict or can be compatible.

NGOs with a focus on heritage preservation articulate different viewpoints in the political and social discourses around renovation of the main bazaar and adjacent old town. However, their agendas are only rarely incorporated into the planning process. Whereas the local NGO LAMO appreciates the improvement of water and road infrastructures in 
the old town, an employee pointed out that the simultaneous demolition of historical houses by the government was of serious concern to them..$^{20}$

In contrast to observations by other studies on slum restructuration in other Indian cities (e.g. Rademacher and Anand 2011), the case of Leh does not display strong alliances between (non-local) NGOs and less powerful inhabitants. Nevertheless, NGOs actively engage in the discourse on socio-ecological processes and Ladakh's development path and also include concerns over the ongoing change in Leh. The director of a local NGO points out the lack of power of local people in current socioeconomic developments: "It's the money, you know. Playing out with the lifestyle of the people. It is being played out somewhere far away. We are getting blown away by the tornado. So, it is inescapable."21 While many NGOs emphasize the danger of uncontrolled social and economic development, they tend to feel a "deep ambivalence ... towards modernity and development" (van Beek 2008:182). Consequently, several NGOs promote the protection of cultural values and practices, which are widely perceived as predominantly Buddhist because of the religious majority, and view Ladakh as a model for sustainable development. ${ }^{22}$

41 The inhabitants' expectations of the large urban renewal programme are generally high. Household studies reveal that respondents almost uniformly hope for improved services. The transformation of the town centre of Leh aims at improving its touristic and economic performance and several actors, especially those working in the tourism business, are expected to make greater profits from an increasing number of visitors coming to Ladakh. However, while some inhabitants of Ladakh seem to benefit from the ongoing transformations and developments, others do not. Migrants from rural parts of Ladakh and seasonal workers from other parts of India or $\mathrm{Nepal}^{23}$ cannot afford to own larger swathes of land in Leh. As a consequence, they often settle in the degraded old town, where houses are of comparatively-lower standard and rents affordable, or Leh's peripheries with only rudimentary access to infrastructures. ${ }^{24}$ These economically marginalized groups are subject to "politics of forgetting" (Fernandes 2004), while the new urban middle classes of India show a "growing cultural visibility" (Fernandes 2004:2415) in urban spaces. Against the backdrop of current socioeconomic change in Leh, social disparities are likely to increase and become more visible in urban spaces. Some residents support the current development scheme, as the statement of an interviewee reveals:

We want Leh town, want to see the beauty of this city. This is our main city, isn't it? Many tourists are coming and going and they get the facilities. Good facilities in our town, you know. There are many tourist attractions..$^{25}$

The perception of the aesthetics of the so-called beautification, however, remains a contested topic among Leh's inhabitants. Another resident stated: “We don't want that. It is not cooperated with our landscape and culture here." ${ }^{" 26}$ Abdul Ghani Sheikh, a historian and older citizen of Leh, summarizes these ambivalent perceptions about the development of the main bazaar in retrospect:

Leh bazaar is now more beautiful and clean. It has many more shops and is lined with concrete buildings. But is has lost much of its old charm and glory. Poplar trees are no more. Under their shadow, people took rest in summer. No cultural or social activities are held in the bazaar, only the movement of traffic is seen day and night. (Ghani Sheikh 2014:30)

43 Beautification projects in Leh have not been stand-alone programmes, but have been realized as part of the large JNURRM urban renewal programme, which originally aimed 
at the improvement of water infrastructures, waste management and road networks. While beautification in large cities is often steered by local middle classes and their urban imaginaries (Mawdsley 2004:81-84), the social system in Ladakh differs historically from other parts of India and does not display a drastically divided urban society (e.g. Gururani 2013). However, economic stratification has intensified with the shift from subsistence-oriented livelihoods to a market economy. The current boom in the tourism sector is a major manifestation of socioeconomic change and has a direct impact on Leh's phenotype. Especially non-local middle class groups that come as tourists to the region become more important within the current renegotiation of aesthetic visions of urban space in Leh. At the same time, a growing local middle class is gaining greater influence on urban transformations through private investments such as hotels, restaurants or shops. Moreover, the government policies align with the interests of certain groups, especially the economically well-off more influential private businessmen who are interested in maximizing their profits from tourism and at the same time are evolving as an increasingly powerful middle class.

Comparing Leh's beautification with similar processes observed in larger Indian cities, one can see that motivations for and effects of such projects differ widely. Whereas in Indian metropolises, mega projects and aspirations of making cities "world-class"-like often drive beautification processes, in Leh the main reason is to improve the town's quality as a tourist destination. Cases from Delhi and other large agglomerations show that urban middle classes have substantial influence on urban renewal (Baviskar 2003; Gandy 2008; Follmann 2014). Nuisance, environmental concerns and health issues are often given as causes for the demolishing or the resettlement of slums (Ghertner 2015): "The result is a form of spatial purification, named beautification, and cleaning to purge the city of the poor" (Rademacher and Sivaramakrishnan 2013:24). In Leh, a section of the old town was declared as a slum, but nevertheless, socio-ecological and spatial differences are not as extreme as in larger Indian cities. The influence of Leh's local middle classes on urban restructuring has increased, but is currently still less important than the perceived expectations of non-local middle classes visiting Ladakh.

\section{Conclusion}

Various actors are involved in the beautification process, with beautification carrying different meanings for all of them. The beautification of the main bazaar, and its perceived contribution to Leh's touristic and economic development, lie at the core of the regional Hill Council's efforts to implement an urban renewal scheme of the central government. It is assumed that tourists mainly expect relaxation and consumption spaces. This has motivated private businessmen to build new shops, restaurants and hotels, thereby restructuring the town. NGOs and cultural heritage preservationists seem to be less powerful or influential.

We have shown that the ideas involved in the creation of urban nature are grounded in powerful imaginaries. First, Leh's historic function as a trade centre is part of the discourse, mainly emanating from NGOs, historians and politicians. Second, the definition of aesthetics and design is influenced by the case of another mountain town of perceived cultural and religious similarity: The vision of Leh bazaar's appearance grows out of not only historical reference, but also of the example of Gangtok, Sikkim. 
Processes of beautification in the case of Leh are embedded in wider discussions of urban development and modernity (Robinson 2006). Leh is a small town located at the periphery of the Indian nation state, perceived as a remote and backward area that seemingly needs to be developed. Further research is required to analyse the relation between the nation state and other areas of local (urban) governance, in order to gain deeper insights into the postcolonial urban politics of the Indian state (Roy 2014).

The findings from this case can contribute to the ongoing debate on UPE in the South (Zimmer 2015). Furthermore, the study adds empirical evidence to theoretical perspectives on state-led, neoliberal urban developments in small towns in India (e.g. Zimmer, Cornea and Véron 2016). Leh is an example of the socionatural (re-)production of urban space in high mountain regions with their specific sociocultural and environmental conditions.

9 We concentrated on the diverse actors involved in urban restructuration and on the aspects of the imaginaries of urban middle classes. The case study highlights the need to consider local particularities when assessing the beautification of cities, as others have argued (e.g. Holifield and Schuelke 2015; Lawhon, Ernstson and Silver 2014; Zimmer, Cornea and Véron 2016; see introduction to this special issue). By highlighting the multifaceted processes of urban renewal and the actors behind it, this articles aims to enrich the field of research on beautification in cities of the Global South. More studies on this topic can surely be undertaken in other-small or large-cities in South Asia.

As the beautification project in Leh is ongoing, it remains to be seen how the local population will perceive it as it proceeds and profit from the changes. A further discussion on beautification in Leh would definitely contribute to interdisciplinary research, including insights from fields like architecture, urban planning or history.

\section{BIBLIOGRAPHY}

Aggrawal, Ravina. 2004. Beyond Lines of Control: Performance and Politics on the Disputed Borders of Ladakh, India. Durham, Great Britain: Duke University Press.

Alexander, André. 2007. Towards a Management Plan for the Old Town of Leh: Structuring a Plan for the Preservation of an Endangered Townscape and Revitalization of Traditional Structures. Tibet Heritage Fund, Berlin. Retrieved March 5, 2016 (http://www.tibetheritagefund.org/media/download/ leh_conservation_aa.pdf).

Alexander, André and Andreas Catanese. 2014. "Conservation of Leh Old Town: Concepts and Challenges." Pp. 348-63 in Art and Architecture in Ladakh: Cross-Cultural Transmissions in the Himalayas and Karakoram, edited by E. L. Bue and J. Bray. Leiden, The Netherlands: Brill's Tibetan Studies Library.

Anand, Nikhil and Anne Rademacher. 2013. "Housing in the Urban Age: Inequality and Aspiration in Mumbai." Pp. 201-24 in Ecologies of Urbanism in India: Metropolitan Civility and Sustainability, edited by K. Sivaramakrishnan and A. Rademacher. Hong Kong, China: Hong Kong University Press. 
Baviskar, Amita. 2003. "Between Violence and Desire: Space, Power and Identity in the Making of Metropolitan Delhi.” International Social Science Journal 175(55): 89-98. doi: 10.1111/1468-2451.5501009.

Beek, Martijn van. 1996. "Identity Fetishism and the Art of Representation: The Long Struggle for Regional Autonomy in Ladakh." PhD dissertation, Department of Development Sociology, Cornell University, Ithaca, New York.

Beek, Martijn van. 1999. "Hill Councils, Development, and Democracy: Assumptions and Experiences from Ladakh.” Alternatives 24(4): 435-59. Retrieved April 2, 2016 (http:// www.jstor.org/stable/40644974?seq=1\#page_scan_tab_contents).

Beek, Martijn van. 2000. "Lessons from Ladakh? Local Responses to Globalization and Social Change." Pp. 250-66 in Globalization and Social Change, edited by J. D. Schmidt and J. Hersh. London, Great Britian: Routledge.

Beek, Martijn van. 2001. "Public Secrets, Conscious Amnesia, and the Celebration of Autonomy for Ladakh." Pp. 365-90 in States of Imagination Ethnographic Explorations of the Postcolonial State, edited by T. B. Hansen and F. Stepputat. Durham, London, Great Britain: Duke University Press.

Beek, Martijn van. 2008. “Imaginaries of Ladakhi Modernity." Pp. 165-88 in Tibetan Modernities: Notes from the Field on Cultural and Social Change, edited by R. Barnett and R. Schwartz. Leiden, The Netherlands: Brill Academic Publishers.

Beek, Martijn van and Kristoffer Brix Bertelsen. 1997. "No Present Without Past: The 1989 Agitation in Ladakh." Pp. 43-65 in Recent Research on Ladakh 7. Proceedings of the $7^{\text {th }}$ Colloquium of the International Association for Ladakh Studies held in Bonn/Sankt Augustin, 12-15 June 1995, edited by T. Dodin and H. Räther. Ulm, Germany: Ulmer Kulturanthropologische Schriften 9.

Brosius, Christiane. 2010. India's Middle Class: New Forms of Urban Leisure, Consumption and Prosperity . New Delhi, India and Abingdon, Great Britian: Routledge.

Carlino, Gerald A. and Albert Saiz. 2008. "Beautiful City: Leisure Amenities and Urban Growth." FRB of Philadelphia Working Paper 8(22): 1-34. Retrieved June 19, 2016 (http://papers.ssrn.com/ sol3/papers.cfm?abstract_id=1280157).

Census of India. 2001. Final Population Totals. Series 2, Jammu and Kashmir. Chandigarh, [2009].

Census of India. 2011. "Provisional Population Totals. Urban Agglomerations and Cities." Retrieved March 6, 2016 (http://censusindia.gov.in/2011-prov-results/paper2/data_files/ India2/1.\%20Data\%20Highlight.pdf).

Census of India. 2014. “District Census Handbook.” Retrieved March 6, 2016 (http:// www.censusindia.gov.in/2011census/dchb/0103_PART_B_DCHB_LEH\%20\%28LADAKH\%29.pdf).

Coelho, Karen and Nithya V. Raman. 2013. "From the Frying Pan to the Floodplain. Negotiating Land, Water, and Fire in Chennai's Development." Pp. 145-68 in Ecologies of Urbanism in India: Metropolitan Civility and Sustainability, edited by K. Sivaramakrishnan and A. Rademacher. Hong Kong, China: Hong Kong University Press.

Cohen, Barney. 2006. "Urbanization in Developing Countries: Current Trends, Future Projections, and Key Challenges for Sustainability.” Technology in Society 28(1-2): 63-80. doi:10.1016/ j.techsoc.2005.10.005.

Dame, Juliane. 2015. "Multilokalität im Himalaya: Diversifizierung der Lebenssicherung und neue Mobilität in Ladakh, Nordindien.” Pp. 37-40 in Aktuelle Forschungsbeiträge zu Südasien. 5.

Jahrestagung des AK Südasien, 23./24. Januar 2015, Göttingen, edited by J. Poerting and M. Keck. Geographien Südasiens 3. 
Dame, Juliane and Marcus Nüsser. 2008. "Development Perspectives in Ladakh, India." Geographische Rundschau International 4(4): 20-27.

Dollfus, Pascale. 1989. Lieu de Neige et de Genévriers. Organisation Sociale et Religieuse des Communautés Bouddhistes du Ladakh. Paris: Editions du CNRS.

Dollfus, Pascale. 1997. “La Ville de Leh au XIXème Siècle. Une Oasis au Carrefour de l'Inde, du Tibet et de l'Asie Centrale." Pp. 135-67 in Recent Research on Ladakh 7. Proceedings of the $7^{\text {th }}$ Colloquium of the International Association for Ladakh Studies held in Bonn/Sankt Augustin, 12-15 June 1995, edited by T. Dodin and H. Räther. Ulm, Germany: Ulmer Kulturanthropologische Schriften 9.

Edensor, Tim and Mark Jayne. 2012. Urban Theory beyond the West: A World of Cities. Oxon, Great Britian and New York, NJ: Routledge.

Epilogue 2011. "Spalbar Gets Experts from Sikkim to Plan Leh Town.” Epilogue, August, 2011. Retrieved March 8, 2016 (https://issuu.com/epilogue/docs/56.epilogue.2011/42).

Fahmi, Fikri Z., Delik Hudalah, Paramita Rahayu and Johan Woltjer. 2014. "Extended Urbanization in Small and Medium-sized Cities: The Case of Cirebon, Indonesia." Habitat International 42: 1-10. doi:10.1016/j.habitatint.2013.10.003.

Fernandes, Leela. 2004. "The Politics of Forgetting: Class Politics, State Power and the Restructuring of Urban Space in India." Urban Studies 41(12): 2415-30. doi: 10.1080/00420980412331297609.

Fewkes, Jaqueline H. 2009. Trade and Contemporary Society along the Silk Road: An Ethno-History of Ladakh. Abingdon, OX: Routledge.

Follmann, Alexander. 2014. "Delhi's Changing Riverfront: Bourgeois Environmentalism and the Reclamation of Yamuna's Floodplain for a World-class City in the Making." Pp. 121-39 in Ville et Fleuve en Asie du Sud: Regards Croisés, edited by H. Joshi and A. Viguier. Paris, France: Inalco.

Follmann, Alexander. 2015. "Urban Mega-projects for a 'World-class' Riverfront: The Interplay of Informality, Flexibility and Exceptionality along the Yamuna in Delhi, India." Habitat International 45(3): 213-22. doi: 10.1016/j.habitatint.2014.02.007.

Gandy, Matthew. 2006a. "Urban Nature and the Ecological Imaginary." Pp. 62-72 in In the Nature of Cities: Urban Political Ecology and the Politics of Urban Metabolism, edited by N. Heynen, M. Kaika and E. Swyngedouw. London, Great Britain and New York, NJ: Routledge.

Gandy, Matthew. 2006b. "Planning, Anti-planning and the Infrastructure Crisis Facing Metropolitan Lagos.” Urban Studies 43(2): 371-96. doi: 10.1080/00420980500406751.

Gandy, Matthew. 2008. "Landscapes of Disaster: Water, Modernity, and Urban Fragmentation in Mumbai." Environment and Planning A (40): 108-30. doi: 10.1068/a3994.

Gazetteer of Kashmír and Ladák. 1890. Gazetteer of Kashmír and Ladák: Together with Routes in the Territories of the Maharája of Jamú and Kashmír. Compiled (for Political and Military Reference) under the Jurisdiction of the Quarter Master General in India in the Intelligence Branch. Calcutta. Ghani Sheik, Abdul. 2010. Reflections on Ladakh, Tibet and Central Asia. New Delhi, India: Skyline Publications.

Ghani Sheik, Abdul. 2014. "Leh Bazaar: A Study in Historical Importance.” Sheeraza 50(1): 21-30. Ghertner, D. Asher. 2011. "Rule by Aesthetics. World-class City Making in Delhi." Pp. 279-306 in Worlding Cities. Asian Experiments and the Art of Being Global, edited by A. Roy and A. Ong. Oxford, Great Britain: Wiley-Blackwell. 
Ghertner, D. Asher. 2015. Rule by Aesthetics. World-class City Making in Delhi. New York, NJ: Oxford University Press.

Gidwani, Vinay. 2013. "Value Struggles: Waste Work and Urban Ecology in Delhi." Pp. 169-200 in Ecologies of Urbanism in India. Metropolitan Civility and Sustainability, edited by K. Sivaramakrishnan and A. Rademacher. Hong Kong: Hong Kong University.

Goodall, Sarah K. 2004. "Rural-to-urban Migration and Urbanization in Leh, Ladakh: A Case Study of Three Nomadic Pastoral Communities." Mountain Research and Development 24(3): 220-27. Retrieved March 8, 2016 (http://dev.mtnforum.org/sites/default/files/publication/files/5262.pdf ) .

Gooptu, Nandini. 2016. "Divided We Stand: The Indian City after Economic Liberalization." Pp. 216-31 in Routledge Handbook of Contemporary India, edited by K. A. Jacobsen. Oxon, Great Britian and New York, NJ: Routledge.

Gururani, Shubhra. 2013. “Flexible Planning: The Making of India's 'Millennium City,' Gurgaon.” Pp. 119-43 in Ecologies of Urbanism in India. Metropolitan Civility and Sustainability, edited by K. Sivaramakrishnan and A. Rademacher. Hong Kong: Hong Kong University.

Harriss, John. 2007. "Antinomies of Empowerment: Observations on Civil Society, Politics and Urban Governance in India." Economic and Political Weekly 42(26): 2716-24. Retrieved March 12, 2016 (http://www2.ids.ac.uk/futurestate/pdfs/Harriss-EPW-Empowerment300607.pdf).

Heynen, Nik. 2014. "Urban Political Ecology I: The Urban Century." Progress in Human Geography 38(4): 1-7. doi: 10.1177/0309132513500443.

Heynen, Nik, Maria Kaika and Erik Swyngedouw. 2006. In the Nature of Cities: Urban Political Ecology and the Politics of Urban Metabolism. London, Great Britain and New York, NJ: Routledge.

Holifield, Ryan and Nick Schuelke. 2015. "The Place and Time of the Political in Urban Political Ecology: Contested Imaginations of a River's Future." Annals of the Association of American Geographers 105(2): 294-303. doi: 10.1080/00045608.2014.988102.

Kraas, Frauke. 2007. “Megacities and Global Change: Key Priorities.” Geographical Journal 173(1): 79-82. doi: 10.1111/j.1475-4959.2007.232_2.x.

Kraas, Frauke, Surinder Aggarwal, Martin Coy and Günter Mertins. 2014. Megacities: Our Global Urban Future. Heidelberg: Springer.

LAHDC (Ladakh Autonomous Hill Development Council). 2005. "Ladakh 2025 Vision Document." Retrieved March 6, 2016 (http://www.leh.nic.in/pages/VISIONDOCUMENT.pdf).

Latour, Bruno. 1993. We Have Never Been Modern. Cambridge, MA: Harvard University Press.

Lawhon, Mary, Henrik Ernstson and Jonathan Silver. 2014. "Provincializing Urban Political Ecology: Towards a Situated UPE through African Urbanism.” Antipode 46(2): 497-516.

Luczantis, Christian. 2005. “The Early Buddhist Heritage of Ladakh Reconsidered.” Pp. 65-95 in Ladakhi Histories: Local and Regional Perspectives, edited by J. Bray. Leiden, Boston: Brill.

Mathieu, Jon. 2003. "The Mountains in Urban Development: Lessons from a Comparative View." Pp. 15-33 in Alpes-Himalaya-Andes-Alpen-Himalaja-Anden. Histoire des Alpes-Storia delle AlpiGeschichte der Alpen, edited by T. Busset, L. Lorenzetti and J. Mathieu. Zürich, Switzerland: Chronos Verlag.

Mawdsley, Emma. 2004. India's Middle Classes and the Environment. Development and Change 35 (1): 79-103. doi: 10.1111/j.1467-7660.2004.00343.x. 
MC \& LAHDC (Municipal Committee \& Ladakh Autonomous Hill Development Council). 2012. Rajiv Awas Yojana-Pilot Detailed Project Report. Leh Old Town Upgradation under Rajiv Awas Yojana, Unpublished Report, Leh.

Ministry of Housing and Urban Poverty Alleviation. 2015. "Old Schemes (RAY,AHP,JNNURM,RRY).” Retrieved March 6, 2016 (http://mhupa.gov.in/User_Panel/ UserView.aspx?TypeID=1405).

Ministry of Urban Development. 2009. "Urban Infrastructure Development Scheme for Small \& Medium Towns (UIDSSMT). Overview and Salient Features.” Retrieved March 8, 2016 (http:// www.moud.gov.in/sites/upload_files/moud/files/pdf/uidssmt/overview.pdf).

Ministry of Urban Development. 2011. "Jawaharlal Nehru Urban Renewal Mission. Overview.” Retrieved March 6, 2016 (http://jnnurm.nic.in/wp-content/uploads/2011/01/ PMSpeechOverviewE.pdf).

Ministry of Urban Development. 2014. "List of Approved Projects in Transition Phase under UIDSSMT.” Retrieved March 6, 2016 (http://jnnurm.nic.in/wp-content/uploads/2014/05/ UIDSSMT-TP.pdf).

Monclús, Francisco Javier. 2000. “Barcelona's Planning Strategies: From 'Paris of the South' to the 'Capital of West Mediterranean'.” GeoJournal 51: 57-63. doi: 10.1023/A:1010890320915.

Montgomery, Mark R. 2008. The Urban Transformation of the Developing World. Science 319: 76164. doi: 10.1126/science.1153012.

Mooij, Jos. 2007. "Is There an Indian Policy Process? An Investigation into Two Social Policy Processes." Social Policy \& Administration 41(4): 323-38. doi: 10.1111/j.1467-9515.2007.00556.x.

Nagendra, Harini, H. S. Sudhira, Madhusudan Katti and Maria Schewenius. 2013. "Sub-regional Assessment of India: Effects of Urbanization on Land Use, Biodiversity and Ecosystem Services." Pp. 65-74 in Urbanization, Biodiversity and Ecosystem Services. Challenges and Opportunities, edited by T. Elmqvist, M. Fragkias, J. Goodness, B. Güneralp, P. J. Marcotullio, R. I. McDonald, S. Parnell, M. Schewenius, M. Sendstad, K. C. Seto and C. Wilkinson. Dordrecht, The Netherlands: Springer.

Nijman, Jan. 2010. “A Study of Space in Mumbai's Slums.” Tijdschrift voor Economische en Sociale Geografie 101(1): 4-17. doi: 10.1111/j.1467-9663.2009.00576.x.

Nüsser, Marcus, Susanne Schmidt and Juliane Dame. 2012. "Irrigation and Development in the Upper Indus Basin. Characteristics and Recent Changes of a Socio-hydrological System in Central Ladakh, India." Mountain Research and Development 32(1): 51-61. doi: http://dx.doi.org/10.1659/ MRD-JOURNAL-D-11-00091.1.

Petech, Luciano. 1977. The Kingdom of Ladakh, c. 950-1842 A.D. Rome: Italia, Istituto italiano per il Medio ed Estremo Oriente.

Rademacher, Anne and Nikhil Anand. 2011. "Housing in the Urban Age: Inequality and Aspiration in Mumbai." Antipode 43(5): 1748-72. doi: 10.1111/j.1467-8330.2011.00887.x.

Rademacher, Anne and K. Sivaramakrishnan. 2013. "Introduction: Ecologies of Urbanism in India." Pp. 1-41 in Ecologies of Urbanism in India: Metropolitan Civility and Sustainability, edited by K. Sivaramakrishnan and A. Rademacher. Hong Kong, China: Hong Kong University Press.

Ranganathan, Malini. 2015. "Storm Drains as Assemblages: The Political Ecology of Flood Risk in Post-colonial Bangalore." Antipode 47(5): 1300-20. doi: 10.1111/anti.12149. 
Reach Ladakh. 2011a. "Proposal to Make Leh Bazaar a Vehicle-free Zone." Reach Ladakh, September 16. Retrieved March 8, 2016 (http://www.reachladakh.com/archive_details.php? $\mathrm{pID}=682$ ).

Reach Ladakh. 2011b. "Leh Bazaar to Be No Traffic Zone. LAHDC Proposes Strict Traffic Regulation ahead of Tourist Season.” Reach Ladakh, April 11. Retrieved March 8, 2016 (http:// www.reachladakh.com/archive_details.php?pID=572).

Reach Ladakh. 2013. "Leh Beautification Project Worth Rs 217 Crores Inaugurated in Leh." Reach Ladakh, December 25. Retrieved March 8, 2016 (http://www.reachladakh.com/ archive_details.php?pID=2103).

Reach Ladakh. 2015. "Leh Gets its First Eco-Municipal Park at Balkhang." Reach Ladakh, June 4. Retrieved March 8, 2016 (http://www.reachladakh.com/leh-gets-its-first-eco-municipal-park-atbalkhang/2886.html).

Rigzin, Tsewang. 2016. “Let's Re-visit Ladakh 2025-Vision Document.” State Times, February 6. Retrieved March 8, 2016 (http://news.statetimes.in/lets-re-visit-ladakh-2025-vision-document/). Rizvi, Janet. 1996. Ladakh: Crossroads of High Asia. $2^{\text {nd }}$ ed. New Delhi, India: Oxford University Press. Rizvi, Janet. 1999. Trans-Himalayan Caravans. Merchant Princes and Peasant Traders in Ladakh. New Delhi, India and New York, NJ: Oxford University Press.

Rizvi, Janet. 2012. Ladakh: Crossroads of High Asia. $3^{\text {rd }}$ ed. New Delhi, India: Oxford University Press. Robinson, Jennifer. 2006. Ordinary Cities: Between Modernity and Development. Oxon, Great Britian and New York, NJ: Routledge.

Roy, Ananya. 2014. "Slum-free Cities of the Asian Century: Postcolonial Government and the Project of Inclusive Growth.” Singapore Journal of Tropical Geography 35: 136-50. doi: 10.1111/ sjtg.12047.

Shaw, Annapurna. 2013. "Emerging Perspectives on Small Cities and Towns." Pp. 36-53 in Small Cities and Towns in Global Era: Emerging Changes and Perspectives, R. N. Sharma and R. S. Sandhu. Jaipur, India: Rawat Publications.

Simon, David. 2008. "Political Ecology and Development: Intersections, Explorations and Challenges Arising from the Work of Piers Blaikie.” Geoforum 39: 689-707. doi: 10.1016/ j.geoforum.2007.01.011.

Sridhar, Kala Seetharam, A. Vebugopala Reddy and Pavan Srinath. 2011. Changing the Urban Face of Karnataka: Evidence from Three Urban Development Programmes. Bangalore, India: Public Affairs Centre.

Swerts, Elfie, Denise Pumain and Eric Denis. 2014. “The Future of India's Urbanization.” Futures 56: 43-52. doi: 10.1016/j.futures.2013.10.008.

Swyngedouw, Erik. 2004. Social Power and the Urbanization of Water: Flows of Power. Oxford, Great Britain and New York, NJ: Oxford University Press.

Swyngedouw, Erik and Nik Heynen. 2010. "Urban Political Ecology, Justice and the Politics of Scale." Pp. 79-85 in The Blackwell City Reader, edited by G. Bridge and S. Watson. Chichester, Great Britain and Malden, MA: Wiley-Blackwell.

Tiwari, Piyush, Ranesh Nair, Pavan Ankinapalli, Jyoti Rao, Pritika Hingorani and Manisha Gulati. 2015. India's Reluctant Urbanization. Thinking Beyond. London, Great Britian: Palgrave Macmillan UK. 
Véron, René. 2006. "Remaking Urban Environments: The Political Ecology of Air Pollution in Delhi.” Environment and Planning A 38(11): 2093-109. doi: 10.1068/a37449.

Vira, Bhaskar and Shiraz Vira. 2005. “Governing India's Urban Environment: Problems, Policies and Politics." Pp. 29-60 in Urbanization and Governance in India, edited by E. Hust and M. Mann. New Delhi, India: Manohar Publishers.

Zimmer, Anna. 2010. "Urban Political Ecology: Theoretical Concepts, Challenges, and Suggested Future Directions.” Erdkunde 64(4): 343-54. doi: 10.3112/erdkunde.201.

Zimmer, Anna. 2015. “Urban Political Ecology 'Beyond the West': Engaging with South Asian Urban Studies." Pp. 591-603 in The International Handbook of Political Ecology, edited by R. L. Bryant. Cheltenham, Great Britain: Edward Elgar Publishing.

Zimmer, Anna, Natasha Cornea and René Véron. 2016. "Of Parks and Politics. The Production of Socio-Nature in a Gujarati Town." Local Environment: 1-18. doi: 10.1080/13549839.2016.1157157.

\section{NOTES}

1. An official of the Statistical Office in Leh (Interview by Judith Müller, Leh, April 6, 2015) suggests that census data for Leh district of 2011 is controversial. First provisional data stated 63,203 inhabitants for Leh town (Census of India 2011), whereas the Statistical Office in Leh communicated 29,417 as a population number (Interview by Judith Müller, Leh, April 6, 2015) and 45,671 (Interview by Judith Müller, Leh, August 18, 2015).

2. Relates to a "paradise on earth" in Tibet described in the novel Lost Horizon by James Hilton from 1933.

3. Tourism Department, interview by Judith Müller, Leh, August 17, 2015.

4. Police Department, interview by Judith Müller, Leh, August 19, 2015.

5. The size of the towns is not specified; all towns that are not already covered by the JNNURM programme, are eligible (Shaw 2013:45).

6. Launched in December 2005, the programme was supposed to last until 2012 but has been prolonged until March 2017 (Ministry of Housing and Urban Poverty Alleviation 2015). Of the 63 cities covered, all 35 cities with more than 1 million inhabitants were included, as well as every state capital and a few other cities of national importance (Shaw 2013:45). JNNURM has been a response of the Government of India (GoI) under Prime Minister Manmohan Singh to high urbanization rates and the resultant challenges for urban infrastructures and governance. Between 2001 and 2011, the urban population in India rose from 28\% (285 million) (Ministry of Urban Development 2009) to 31\% (377 million) (Census of India 2011).

7. Technical Officer, Public Works Department, interview by Judith Müller, Leh, 28 March 2016.

8. It is interesting to note that the first Hill Council elected in 1995 also visited Sikkim on an exposure tour "to learn what they have done to create a viable, modern, but unmistakably ‘Tibetan' society” (van Beek 2008:185).

9. RAY was renamed to "Housing for All" (Ministry for Housing and Urban Poverty Alleviation 2015). For reasons of simplification, we will call it RAY in this article as we deal with documents from before it was renamed.

10. Leh reached the status of a municipality in 2005 (Alexander 2007). However, the municipal committee has not been elected to this day and thus has a limited base of power (Municipal Committee, interview by Judith Müller, Leh, March 25, 2016).

11. Administrator Municipal Committee, interview by Judith Müller, Leh, March 25, 2016.

12. NGO director, interview by Judith Müller, Leh, April 11, 2016. 
13. However, due to its status under Article 370 of the Indian constitution, Jammu and Kashmir is granted special rights. The state government has to agree to the application of laws, which have been adopted in Delhi. Defence, foreign affairs, finance and communications are excluded from this rule.

14. The argumentation for an autonomous status of Ladakh followed a "communalist strategy," arguing that "Buddhist Ladakh" is at a disadvantage due to political preference for the Muslim population, which is the largest religious group at the state level (van Beek 2001:367; 2004:197).

15. For the prominent example of Helena Norberg-Hodge's influence in Ladakh see van Beek 2008.

16. The most striking example of this mechanism is the case of the Watershed Development Programme, which has led to a significant increase in the number of NGOs in Leh since the 1990s. 17. However, even before Indian independence, religion as opposed to caste had become the “determining factor for identifying communities within Ladakh" (Aggarwal 2004:169).

18. Roads and Buildings Department, interview by Judith Müller, Leh, March 13, 2015.

19. Administrator of Municipal Committee, interview by Judith Müller, Leh, March 25, 2016.

20. NGO Employee, interview by Judith Müller, Leh, March 29, 2016.

21. NGO director, interview by Judith Müller, Leh, April 25, 2015.

22. Examples are LEDeG, Ladakh Environment and Health Organization (LEHO) or the Women's Alliance Ladakh (WAL). They implement various projects under the umbrella of sustainable development, for example in the fields of ecology, agriculture, water supply or women's empowerment.

23. NGO Employee, interview by Judith Müller, Leh, August 5, 2015.

24. Questionnaires, conducted by Judith Müller, Leh, April 2015.

25. Resident of Leh, interview by Judith Müller, Leh, March 26, 2015.

26. Resident of Leh, interview by Judith Müller, Leh, April 7, 2016.

INDEX

Keywords: beautification, urban aesthetics, urban political ecology, small towns, India

\section{AUTHORS}

\section{JUDITH MÜLLER}

Heidelberg Center for the Environment, South Asia Institute, Department of Geography, Heidelberg University

\section{JULIANE DAME}

Heidelberg Center for the Environment, South Asia Institute, Department of Geography, Heidelberg University 